OPEN ACCESS

Edited by:

Stephan Pauleit,

Technical University of

Munich, Germany

Reviewed by:

Tao Lin,

Institute of Urban Environment

(CAS), China

Tenley M. Conway,

University of Toronto

Mississauga, Canada

*Correspondence:

Bernadett Kiss

bernadett.kiss@iiiee.lu.se

Specialty section:

This article was submitted to

Urban Greening,

a section of the journal

Frontiers in Sustainable Cities

Received: 15 July 2020 Accepted: 30 November 2020

Published: 21 January 2021

Citation:

van der Jagt APN, Kiss B, Hirose $S$ and Takahashi W (2021)

Nature-Based Solutions or Debacles?

The Politics of Reflexive Governance for Sustainable and Just Cities.

Front. Sustain. Cities 2:583833. doi: 10.3389/frsc.2020.583833

\section{Nature-Based Solutions or Debacles? The Politics of Reflexive Governance for Sustainable and Just Cities}

\author{
Alexander P. N. van der Jagt ${ }^{1,2}$, Bernadett Kiss ${ }^{3,4 *}$, Shunsuke Hirose ${ }^{5}$ and \\ Wakana Takahashi ${ }^{4}$
}

${ }^{1}$ Copernicus Institute of Sustainable Development, Utrecht University, Utrecht, Netherlands, ${ }^{2}$ Forest and Nature Conservation Policy Group, Wageningen University, Wageningen, Netherlands, ${ }^{3}$ International Institute for Industrial Environmental Economics, Lund University, Lund, Sweden, ${ }^{4}$ School of International Studies, Utsunomiya University, Utsunomiya, Japan, ${ }^{5}$ Center for Spatial Information Science, The University of Tokyo, Tokyo, Japan

With their potential to effectively address multiple urban sustainability challenges, the emerging policy discourse on nature-based solutions seeks to encourage the development of multifunctional nature for sustainable and just cities. Nature-based solutions, however, are vulnerable to co-option by powerful interests in ways that limit their contribution to a broad range of sustainability goals. Reflexive governance arrangements between different types of actors, engaging in continuous and iterative processes of learning and readjustment of institutions and practices, provide a way to address this issue. However, the potential of reflexive governance in increasing commitment to sustainable and just cities, and the role of power struggles in such processes, remains underexplored. To study this question, we undertake a comparative case study analysis of nature-based solutions in Utrecht (The Netherlands), Malmö (Sweden), and Utsunomiya (Japan). These are analyzed using a framework structured around the dimensions of system analysis, goal formulation, and strategy implementation, to which we apply a justice lens. The findings demonstrate reflexive processes in each of the studied cases, but the justice dimension is not always explicitly taken into account or clearly influenced in positive ways. We unveil tensions between the ideal of sustainable and just cities and the reality of urban nature-based solution initiatives being partially dependent on the power structures they seek to influence for their continued existence. We argue against dismissing the studied cases as neoliberal projects on these grounds. Reflexive governance for sustainable and just cities entails a continuous struggle for dominance between different ideas and interests. Moreover, the battlegrounds for these struggles may look very different across sociopolitical contexts. Provided that justice considerations are continually present, reflexive governance of urban nature-based solutions is likely to contribute to more sustainable and just cities.

Keywords: nature-based solutions, reflexive governance, environmental justice, mosaic governance, sustainable cities, urban transformation, urban greening, adaptive management 


\section{INTRODUCTION}

In many cities, nature is under pressure as a result of urbanization, urban densification strategies, and government austerity (Dupras et al., 2015; Haaland and van den Bosch, 2015). This is further exacerbated by factors such as limited ecological knowledge in the urban planning and development sector (Zhou et al., 2019); poor inventorying, monitoring, and assessing of existing urban nature (Haaland and van den Bosch, 2015; van der Jagt and Lawrence, 2019); and the general absence of long-term financing opportunities for bottom-up urban greening initiatives (Mattijssen et al., 2017). This loss of urban nature is problematic given the increased urgency for cities to prioritize sustainable development. Inclusive access to green space and cultural heritage protection are, for instance, explicitly acknowledged in the United Nations Sustainable Development Goal (SDG) 11Make cities and human settlements inclusive, safe, resilient, and sustainable (United Nations, 2015).

An emerging policy discourse around nature-based solutions (NBSs) seeks to stress this point by drawing attention to the potential of nature as a multifunctional sustainability solution delivering value for sustainable and just cities (European Commission, 2015; Maes and Jacobs, 2017; Dorst et al., 2019). Whereas many technological sustainability innovations provide single benefits (e.g., less carbon emissions), urban NBSs provide a multitude of values (van der Jagt et al., 2020), including, e.g., climate change adaptation (Kabisch et al., 2017), halting unprecedented biodiversity loss (Baldock et al., 2015), improving environmental literacy and sustainable behavior (Wals and Benavot, 2017), restoration from stress and mental fatigue associated with urban lifestyles (van den Berg et al., 2007; van der Jagt et al., 2017a), tackling loneliness and a dwindling sense of community (Sullivan et al., 2004; De Vries et al., 2013), addressing segregation of different sociocultural groups (Peters et al., 2010), air and water purification (Pugh et al., 2012; Masi et al., 2018), providing opportunities for recreation and physical activity (Sugiyama et al., 2010), greening the economy (Elmqvist et al., 2015), and equitable access to healthy and sustainable food (Horst et al., 2017).

To achieve sustainable and just cities, recent literature on urban NBSs has called for reflexive arrangements between actors from different backgrounds (Kabisch et al., 2016; Gulsrud et al., 2018)_inclusive and accessible nature relies on institutions understanding different social constructions of nature (Buizer et al., 2016). Such engagement with different types of actors and ways of knowing fits with a broader trend of environmental governance turning more decentralized, area-specific, and interactive (Driessen et al., 2012; Hajer et al., 2015)-i.e., a shift from "government to governance" (Hysing, 2009). Consequently, a bourgeoning body of literature is exploring normative questions around who is involved, how, and to which ends in these governance processes, resulting in the emergence of concepts and approaches such as polycentric governance (Pahl-Wostl, 2009; Ostrom, 2010), adaptive or integrated governance (Gupta et al., 2013), and reflexive governance (Voß and Kemp, 2006). More recently, the mosaic governance (Buijs et al., 2016b, 2018) and "Nature-Based Thinking" (Randrup et al., 2020) frameworks were developed presenting a normative perspective on governing urban NBSs. In line with these developments, recent studies show that collaborative governance of NBSs such as urban green and blue infrastructure has become commonplace in many European cities. This varies from strategic involvement of nongovernmental actors in policy development to comanagement of green spaces and green barters with businesses developing or maintaining urban nature in return for monetizing the values of these sites (Buijs et al., 2016a; van der Jagt et al., 2016; Frantzeskaki, 2019). In such arrangements, municipalities often retain a central role, fitting a longer tradition of municipal responsibility for the provision of urban nature in the Global North (Konijnendijk et al., 2006; Mees and Driessen, 2011).

Together with a shift from government to governance, researchers are also witnessing a tendency for more openended, non-linear approaches to managing urban processes (Voß et al., 2006). Some even argue that cities have become spaces for continuous experimentation, as a key means of urban sustainability governance (Evans, 2011; Karvonen, 2018). Proponents of reflexive governance-"a mode of steering that encourages actors to scrutinize and reconsider their underlying assumptions, institutional arrangements and practices" (Hendriks et al., 2007)-consider such openendedness and the inclusion of multiple disciplines and worldviews in decision-making as a necessary step to part with business as usual and achieve a more sustainable society (Voß and Kemp, 2006; Hendriks and Grin, 2007; Smith et al., 2010; Voß and Bornemann, 2011; Feindt and Weiland, 2018).

In recent accounts of reflexive governance research, actorcentered processes are of key concern. Metze and Van Zuydam (2018) discuss how innovative boundary concepts play an important role in enabling reflexivity-support by facilitating actors can deepen this reflexivity (Rodríguez et al., 2018). Networks are also discussed as facilitators of "negotiated connected contracts" involving a broad range of societal actors (Weiner, 2018) or can constrain reflexivity when strong trustand value-based relationships are prioritized over reflexive practice (McNutt and Rayner, 2018). These studies touch upon many aspects of actor-centered processes of reflexivity from community learning (Rodríguez et al., 2018) and network management (McNutt and Rayner, 2018) to learning at the level of political systems (Meadowcroft and Steurer, 2018). Surprisingly, recent studies mostly remain silent on the role of politics - the struggle for dominance between actors with divergent interests and ideas (Voß and Bornemann, 2011). This is problematic as by neglecting the role of politics at different scales, reflexive governance becomes very similar to conceptualizations of adaptive management, with a strong focus on collaborative learning and experimentation at the micro level (Voß and Bornemann, 2011). By blocking out the role of politics, one ignores the point that urban experiments are vulnerable to capture and domination by powerful interest groups, which is ostensibly threatening their open-ended nature (Bulkeley and Castán Broto, 2013) and jeopardizes processes directed at inclusive and sustainable urbanization.

Such risk for domination of reflexive governance agendas and processes by incumbent regime actors and institutions 
was also highlighted in a number of earlier studies on this concept (Hendriks and Grin, 2007; Kemp et al., 2007; Voß and Bornemann, 2011; Stirling, 2014). However, these contributions analyzed reflexive governance at the macro-scale of sectors and countries-a level at which there is limited scope for bottom-up initiative and where powerful actors have a clear stake in narrowing down system framings, reducing flexibility, and challenging open-endedness. We argue that reflexive arrangements can potentially be more impactful at the micro- and meso-scales of neighborhoods and cities, especially if involved actors can engage in "shadow advocacy" to challenge dominant interests and ideas. By this we mean the formation of informal networks that operate outside mainstream decisionmaking processes (e.g., Brown et al., 2013). Recent authorship on the concept of mosaic governance shows how such reflexive arrangements at different urban levels, both horizontally and vertically, may be key to the development of urban NBSs (Buijs et al., 2016b, 2018).

Building upon these insights, the aim of this study is to explore the functioning of reflexive governance in practice, the extent to which it becomes politicized, and if and how it can deliver upon the promise of sustainable and just cities. We study the politics of reflexive governance in relation to the topic of urban NBSs, given the potential of this type of innovation to contribute to both sustainable and just cities. We selected three cases of urban NBS development in the cities of Utrecht (The Netherlands), Malmö (Sweden), and Utsunomiya (Japan). In each of these, a reflexive governance approach is observed-although not explicitly described as such by the stakeholders involved. The cases highlight how initiatives are aiming to push system constraints limiting sustainable and just cities, which we illustrate by discussing reflexivity in building system understandings, goal setting, and strategy implementation. We pay particular attention to questions around actor engagement with power dynamics and evolutionary processes in knowledge and resource integration. We deliberately selected cases across different contexts to help build an understanding of how sociopolitical factors influence reflexive governance dynamics.

\section{THEORETICAL FRAMEWORK}

\section{The Concept of Reflexive Governance}

Reflexivity, literally "to turn or bend back on oneself" (Hendriks and Grin, 2007, p. 334), has been described as a mode of governance aimed at coming to terms with the sustainability implications of industrial modernization (Voß and Kemp, 2006). It implies a "reflexive type of reflection," targeting the unintended consequences of agents' actions as well as the associated underpinnings of governance itself - "the constellation of authoritative rules, institutions, and practices by means of which any collectivity manages its affairs" (Ruggie, 2004, p. 504). These are the products of historical processes and shape the conduct of actors in powerful ways while not always fit for purpose given modern-day societal challenges. For example, traditional innovation policies have a somewhat one-sided focus on economic development, technologies, and competitiveness (Lindner et al., 2016), which is difficult to harmonize with sustainable development. Reflexive governance provides a means to "break through the dominance of the past and history over the future" (Grin et al., 2010, p. 234), to redraw the system boundaries by including future generations, different geographical scales, and various domains of knowledge production (Voß and Kemp, 2006).

Voß and Kemp (2006) describe reflexive governance as a mode of governance that needs to be flexibly adapted through the ongoing pursuit and integration of knowledge about its effects and effectiveness, one that is also likely to change over time given socioecological and sociotechnical system dynamics influencing the targets for transformative change. It typically brings together different types of knowledge and perspectives on problems and champions continuous learning in order to engage with uncertainties and unintended consequences. Consequently, it embraces "the full, messy, intermingled natural reality" (Voß and Kemp, 2006, p. 5), as opposed to the modernist practice of problem-solving through specialist perspectives on narrow problem definitions. Reflexive governance builds on the principle that system dynamics can never be fully appraised because different actors tend to vary in their understandings of system boundaries and how best to prioritize, achieve, and assess different sustainability goals, e.g., related to climate, biodiversity, public health, green growth, and social justice (Smith and Stirling, 2010; Hodson et al., 2017; Kronenberg and Andersson, 2019). Consequently, pathways to sustainability (i.e., commitments) are opened up to continuous negotiation and reinterpretation (Smith and Stirling, 2010). It is in this very process of iterative reinterpretation that an understanding is built of the complex realities of socioecological and sociotechnical systems, eventually enabling one to "break through the modernistic boundaries created by rational planning" (Lawrence and Molteno, 2012, p. 295). Building on these views, we understand reflexive governance as a mode of governance that "includes the perspectives, values, and norms of a variety of actors, which in turn has consequences for the interventions of the governance system" (Feindt and Weiland, 2018, p. 665).

\section{Reflexive Governance for Just Cities}

The ambition of building sustainable and just cities is high on the political agenda as reflected in SDG 11 and in the high number of EU-funded projects with a focus on aligning urban sustainability and justice (Kotsila et al., 2020). The concept of just cities is understood as the incorporation of democracy, diversity, and equity into urban governance (Fainstein, 2010), with the ultimate goal of improved human well-being. In this context, justice as a societal process or action helps to correct (or aggravate) social inequities, which in turn can lead to inclusivity and equity. In practice, just cities can be realized through both recognizing and eliminating conditions creating injustices, while enabling and strengthening conditions that allow for fair resource distribution. In this context, three types of justice can be distinguished. First, distributional justice is about providing inclusive access to the benefits of sustainable infrastructures. Second, recognition justice is about providing racially and ethnically inclusive political and urban regeneration processes in a fitted institutional structure. Third, procedural justice is about recognizing and removing 
barriers to limited citizen participation in urban planning, while opportunities for knowledge brokerage, stewardship, and the role of civil society are strengthened (Fraser, 2007; Schlosberg, 2009; Toxopeus et al., 2020).

Based on this, we argue that processes of reflexive governance in cities can only be considered successful if contributing to both sustainability and justice. However, the pursuit of reflexive learning and experimentation in real-world settings is rarely a conflict-free process given power struggles, democratic legitimacy concerns, and organizational bureaucracies attempting to control and structure organizational processes in a top-down way (Hendriks and Grin, 2007; Voß and Bornemann, 2011; Lawrence and Molteno, 2012). These struggles can take place within a particular governance arrangement but equally between multiple competing urban governance arrangements (Hodson et al., 2017). We aim to scrutinize how reflexive governance approaches may or may not contribute to just cities by paying attention the following aspects:

- Engaging a diverse array of actors: a type of approach attempting to engage with a higher diversity of knowledge from a diverse and multilevel array of actors compared to mainstream governance, which requires openness by all involved to reinterpret their assumptions, practices, concepts, etc. (Voß and Kemp, 2006; Hendriks and Grin, 2007; Feindt and Weiland, 2018);

- Scope for discussion and conflict: a type of approach that lets go of the idea of narrow problem definitions and perfect solutions-providing scope for more discussion and potentially the surfacing of conflicts in decision-making arenas (Hendriks and Grin, 2007; Voß and Bornemann, 2011).

\section{Reflexive Governance for Urban Nature-Based Solutions}

The concept of reflexive governance has been popular to guide the development of transition-oriented policy frameworks with long-time horizons within the realm of sociotechnical systems such as energy provision, most notably using the Transition Management approach (Kemp and Loorbach, 2006; Voß et al., 2009). It has often been applied to study or guide the process of national policy-making that builds upon social learning between government officials, scientists, and a broad range of other stakeholders. Concerning urban NBSs, which do not fit into a particular policy domain such as energy, water, or transportation (van der Jagt et al., 2020), reflexivity has mainly been studied in relation to specific on-the-ground NBSs initiatives-physical interventions or policy plans-in cities. For example, Kabisch et al. (2016) discuss the need for reflexive arrangements between actors with different epistemic backgrounds in order to engage in joint knowledge development, planning, and governing of NBSs. Gulsrud et al. (2018) present the case of Melbourne's Urban Forest Strategy as an example of an urban policy framework that not only has been developed based on a cocreative process, but also integrates local knowledge into the governance of NBSs through, e.g., neighborhood-specific cogovernance forums. At the same time, other components of this program such as the Urban Forest Fund-providing public coinvestment to greening initiatives on private land (Frantzeskaki et al., 2019) — are prone to aggravate representational and distributional injustices, for example, by prioritizing the representations of nature by the wealthy elite over those by actors with less capacities and fewer resources.

To reduce the risk of NBSs getting "appropriated as part of a neoliberal planning discourse" (Scott et al., 2016, p. 268), there is a need for strategic planning of urban NBSs initiatives in cities, while at the same time responding to the interests and beliefs of different sociocultural groups. This idea of reciprocal relationships between strategic planning and the practices of active citizens, where policy seeks to steer collective action while also being responsive in a place-specific, situated, sense, is at the root of the "mosaic governance" approach (Buijs et al., 2016b, 2018). It can be described as a type of governance that is sensitive to "the physical diversity of urban green spaces, the cultural diversity of urban citizens and their use of green spaces and the institutional diversity of how citizens self-organize" (Buijs et al., 2016b). Through this, it seeks to encourage a mosaic of landscapes as well as governance approaches-cocreated with local communities-across the city. Mosaic governance has been shown to improve the potential for scaling-up and scaling-out urban NBSs-bottom-up initiatives can successfully establish themselves and expand over time through a supportive and responsive policy context (Buijs et al., 2018).

Based on these insights on reflexively governing urban NBSs, we identify a number of specific concerns that together inform our approach to analyzing their justice implications. First, NBSs need to be implemented across urban neighborhoods with different sociocultural practices shaped through storytelling, interactions with biodiversity, and preferred green and blue space activities (Botzat et al., 2016; Buizer et al., 2016). Therefore, it is vital that reflexive governance of urban NBSs takes a context-sensitive approach, engaging different sociocultural and/or demographic groups depending on the neighborhood involved. Second, developing NBSs involves the mobilization of different professional disciplines, some of which, e.g., landscape architects, urban ecologists, or health professionals, tend to be underrepresented or sidelined in urban development regimes as a result of a preference for gray over nature-based sustainability technologies (Bush and Doyon, 2019). Hence, there is a need for empowering these professions where possible in order to improve the integration of urban NBSs in mainstream urban development practice. Third, there are challenges around the distribution of NBSs across cities, with citizens in advantaged neighborhoods often having access to more or higher-quality public amenities, including green spaces. This can be explained by differences in capacities and resources, which puts some communities at an advantage in abilities to self-organize, partner with coinvestors, and lobby the municipality for NBS development (Wolch et al., 2014; Haase et al., 2017). Consequently, reflexive governance of urban NBSs needs to heed the extent to which such spatial imbalances in NBS investment are taken into account and compensated for.

Conflict is likely to arise when actors in powerful positions get tied up in reflexive governance processes. Such actors may seek to disengage with justice concerns, thereby exacerbating 
these. Alternatively, when marginalized voices are included, powerful actors may still be unwilling to reconsider their goals and practices in response to these. This is particularly a risk for hybrid governance arrangements involving both public and private actors-arrangements that are increasingly common for delivering and maintaining urban NBSs (van der Jagt et al., 2016; Droste et al., 2017). That is, these projects tend to rely on coinvestment by private actors with no particular interest in ensuring democratic procedures or fair distributions of natural assets over a city (Toxopeus et al., 2020).

\section{Parallels and Differences With Mosaic Governance}

The mosaic governance framework (Buijs et al., 2016b, 2018) provides a pioneering approach for the study of reflexive arrangements in relation to NBSs at the scale of the city. There are important parallels between mosaic governance and the approach to studying reflexive governance taken in this study. First, mosaic governance assumes a need for mutual steering between public administrations-urban municipalities in this case-and active citizens developing, supporting, and maintaining NBSs. Consequently, it rejects modern understandings of how to structure formal institutions, e.g., involving a small number of expert decision-makers distributed over different functional domains organized in nested layers (Cleaver, 2002). Second, mosaic governance seeks to connect with socially and culturally embedded environmental knowledge and practice. Relating this to the subject of our study, we contend that urban NBSs cannot be sustainably governed or mainstreamed using a "one-size-fits-all" approach (Droste et al., 2017; van der Jagt et al., 2017b). Third, we draw inspiration from the mosaic governance framework in studying reflexive governance at the micro- and meso-scales of neighborhoods and cities.

In other important respects, however, our understanding of reflexive governance departs from how actor engagement and mutual learning are conceptualized in the mosaic governance framework. First, we are not exclusively interested in active citizen groups and accommodating their diverse support needs, by which we want to acknowledge that nature-based urban futures also rely on the engagement of the private sector and the third sector more broadly (Kabisch et al., 2016; van Ham and Klimmek, 2017) - these can also take the role of steering actors. Second, in our understanding, the concept of reflexive governance more explicitly underwrites the importance of continuous and iterative social learning and experimentation involving different types of actors. For example, while one-off financial support by a municipality to a citizen group qualifies as mosaic governance (Buijs et al., 2018), it would be incompatible with the notion of reflexive governance. Third, reflexive governance more clearly articulates the need for the mobilization of different types of actors in determining the problem definition, formulating goals and implementing the strategy. This is unlike the mosaic governance approach, which assumes that the municipality will act as custodians of an inclusive approach (Buijs et al., 2018), without critically analyzing if and how this is achieved. Despite these differences, we anticipate that the present conceptualization of reflexive governance contributes to further theory building on mosaic governance.

\section{METHODS}

We undertook a case study analysis with a comparative design to study the relationship between reflexive governance and outcomes for just and sustainable cities across different contexts (Perri 6 and Bellamy, 2011). We selected three casesFood for Good food garden in Utrecht (The Netherlands), the Koggen green roof in Malmö (Sweden), and Kamagawa Vision for neighborhood regeneration in Utsunomiya (Japan)to investigate and demonstrate the operation of reflexive governance in practice.

The three cases were drawn from a larger set of in-depth case studies of urban NBSs collated as part of the EU-funded NATURVATION research project and a smaller set of Japanese in-depth case studies. The Japanese case studies were undertaken with the implicit aim to compare the governance of NBSs across Europe and Japan. An analytical framework and a case study template were developed in the NATURVATION project, which guided the in-depth analysis of the cases in both these datasets. The case studies served to understand the emergence, governance, and structural conditions enabling (or constraining) the development and mainstreaming of urban NBSs across different cities. In addition, these also mapped the impacts and implications of NBSs, contradictions and contestations around NBSs, and the innovativeness of NBSs vs. conventional measures. These aspects form the basis of our analysis of how reflexive governance plays out in practice, with a particular focus on the coproduction of policy instruments and practices by societal actors.

The case selection from these two broader datasets was guided by the primary aim of this study and a number of related key criteria. These included the participation of diverse actors with different epistemic backgrounds; evidence of a coproduced outcome, e.g., policy instruments and/or practices; and data availability related to these aspects over a relatively long time horizon (beyond the dedicated 6 months of case study research). Furthermore, we also deliberately selected cases representing diverse socioeconomic and sociopolitical contexts. The contextual differences and similarities offer a rich basis for comparison of the underlying principles of reflexive governance processes and allow for developing a deeper understanding of how structural conditions influence the potential for reflexive governance of NBSs.

The case studies were construed based on primary and secondary data on the selected NBSs (Patton, 2014). Primary data were collected through 20 semistructured interviews (eight in Malmö, seven in Utrecht, five in Utsunomiya), one mobile laboratory (Bulkeley et al., 2016) in each city, events, observational study visits, and informal discussions with relevant actors. We held interviewees, mobile laboratories and informal discussions with representatives of knowledge institutions (e.g., research groups), municipal and regional authorities (e.g., urban 
re/development, planning and housing agencies, health care), non-governmental organizations, community groups, utilities (e.g., energy, waste, water), and relevant businesses (e.g., architecture, design, engineering). Secondary data were obtained from a document analysis of academic and gray literature related to the selected cases, including policy documents and media outputs. Interviews were audio-recorded (provided participants agreed with this), transcribed, and thematically analyzed. Prior to interviews, participants were briefed about the aims of the study and the data processing procedure and presented with a consent form asking for their explicit permission to participate, including questions on anonymity and interview recording. Recorded interviews were transcribed, whereas summaries were provided of other types of primary data. The data were analyzed using thematic coding and written up into in-depth case study reports based on a template. This, together with the transcripts, provided the input data for the present analysis. The analysis was conducted in an iterative way; in this process, authors continuously moved back and forth between the dimensions of the analytical framework and the case studies in order to refine guiding questions and coding of the data, which aided the identification of emerging patterns (Pidgeon and Henwood, 1997; Dougherty, 2017).

For the present study, we made use of an analytical framework to assess reflexive governance for sustainability (Voß and Kemp, 2006). This identifies the following analytical dimensions: (I) system analysis, (II) goal formulation, and (III) strategy implementation. We extended the original scope of the framework dimensions given our specific interest in understanding the implications of reflexive governance for sustainable and just cities (Table 1). Additionally, we operationalized the framework by formulating a set of guiding questions for each of the dimensions. Applying this approach aided both the unpacking of reflexive governance for sustainable and just cities within the individual cases and a systematic comparison between cases.

The first dimension, (I) system analysis, has three subdimensions (Figure 1). First, there is a need for transdisciplinary knowledge development, which we understand to be the identification of different types of knowledge applied to describe the challenges to be addressed by the NBSs, and representation in the form of, e.g., multi/trans/interdisciplinary networks, working groups, and other types of collaborations. Second, we searched for evidence for experiments and adaptivity of strategies, policies, and institutions in response to monitoring, evaluation, and other ways of capturing how experiments interact with the interlinked socioecological and sociotechnical systems. Third, we looked for anticipation of long-term systemic effects-the adaptation of strategies in response to effects foreseen at different temporal (e.g., future generations) and spatial (e.g., different neighborhoods, regions or countries) scales and signs for how these have been dealt with in the formulation of strategies.

The second dimension, (II) goal formulation, was unpacked through analyzing whether processes to develop the NBSs were iterative and participatory. To understand participation in goal formulation, we looked at the types of processes used, the
TABLE 1 | Analytical framework to study reflexive governance.

\begin{tabular}{|c|c|c|}
\hline $\begin{array}{l}\text { Strategy } \\
\text { element }\end{array}$ & Strategy requirement & $\begin{array}{l}\text { Analytical units of strategy } \\
\text { requirements }\end{array}$ \\
\hline \multirow[t]{5}{*}{$\begin{array}{l}\text { I. System } \\
\text { analysis }\end{array}$} & $\begin{array}{l}\text { (a) Transdisciplinary } \\
\text { knowledge }\end{array}$ & $\begin{array}{l}\text { - Mobilization of diverse types of } \\
\text { knowledge and concepts }\end{array}$ \\
\hline & $\begin{array}{l}\text { development and } \\
\text { integration to improve } \\
\text { problem definition and } \\
\text { analysis }\end{array}$ & $\begin{array}{l}\text { - Disciplines and networks } \\
\text { from which knowledge and } \\
\text { concepts originate and through } \\
\text { which they travel } \\
\text { - Involvement of } \\
\text { multi/trans/interdisciplinary } \\
\text { working groups }\end{array}$ \\
\hline & $\begin{array}{l}\text { (b) Experiments and } \\
\text { adaptivity of strategies, } \\
\text { policies, and } \\
\text { institutions based on }\end{array}$ & $\begin{array}{l}\text { - Monitoring, evaluation, and } \\
\text { possible reconsideration } \\
\text { of strategies, policies, and } \\
\text { institutions }\end{array}$ \\
\hline & $\begin{array}{l}\text { outcomes of their } \\
\text { interaction with the } \\
\text { world }\end{array}$ & $\begin{array}{l}\text { - Iterative processes and } \\
\text { reflection on previous practices } \\
\text { resulting in adaptive change } \\
\text { - Learning as reflected in } \\
\text { strategies, policies, } \\
\text { and institutions }\end{array}$ \\
\hline & $\begin{array}{l}\text { (c) Anticipation of } \\
\text { long-term systemic } \\
\text { effects of actions }\end{array}$ & $\begin{array}{l}\text { - Indirect effects anticipated in } \\
\text { relation to the nature-based } \\
\text { solutions } \\
\text { - Action strategy responsive to } \\
\text { anticipated effects }\end{array}$ \\
\hline $\begin{array}{l}\text { II. Goal } \\
\text { formulation }\end{array}$ & $\begin{array}{l}\text { Iterative and } \\
\text { participatory goal } \\
\text { formulation }\end{array}$ & $\begin{array}{l}\text { - Processes and actors in } \\
\text { (sustainability) goal formulation } \\
\text { - Features of goal formulation } \\
\text { over time (open, flexible, just) }\end{array}$ \\
\hline $\begin{array}{l}\text { III. Strategy } \\
\text { implementation }\end{array}$ & $\begin{array}{l}\text { Interactive process to } \\
\text { integrate knowledge } \\
\text { and resources and } \\
\text { ensure support }\end{array}$ & $\begin{array}{l}\text { - Means of knowledge and } \\
\text { resource integration } \\
\text { - Actors from different } \\
\text { disciplines and backgrounds } \\
\text { involved in developing } \\
\text { collective approach }\end{array}$ \\
\hline
\end{tabular}

involvement of different groups of actors and, related to this, the extent to which goals were set in an open, flexible, and just way.

The third dimension, (III) strategy implementation, was analyzed by tracing if the collective strategy to deliver upon the goals was based on integrated knowledge from various disciplines and pooled resources and, if so, who has been contributing what. A collective strategy can materialize as a physical intervention delivered by a collective of actors or as coproduced strategies, policies, or visions existing in a written form.

\section{RESULTS AND ANALYSIS}

Below we present the findings of the three studies that have been analyzed using the analytical framework for reflexive governance presented in Table 1. A condensed overview of the findings is provided in Supplementary Table 1. 


\section{System Analysis}

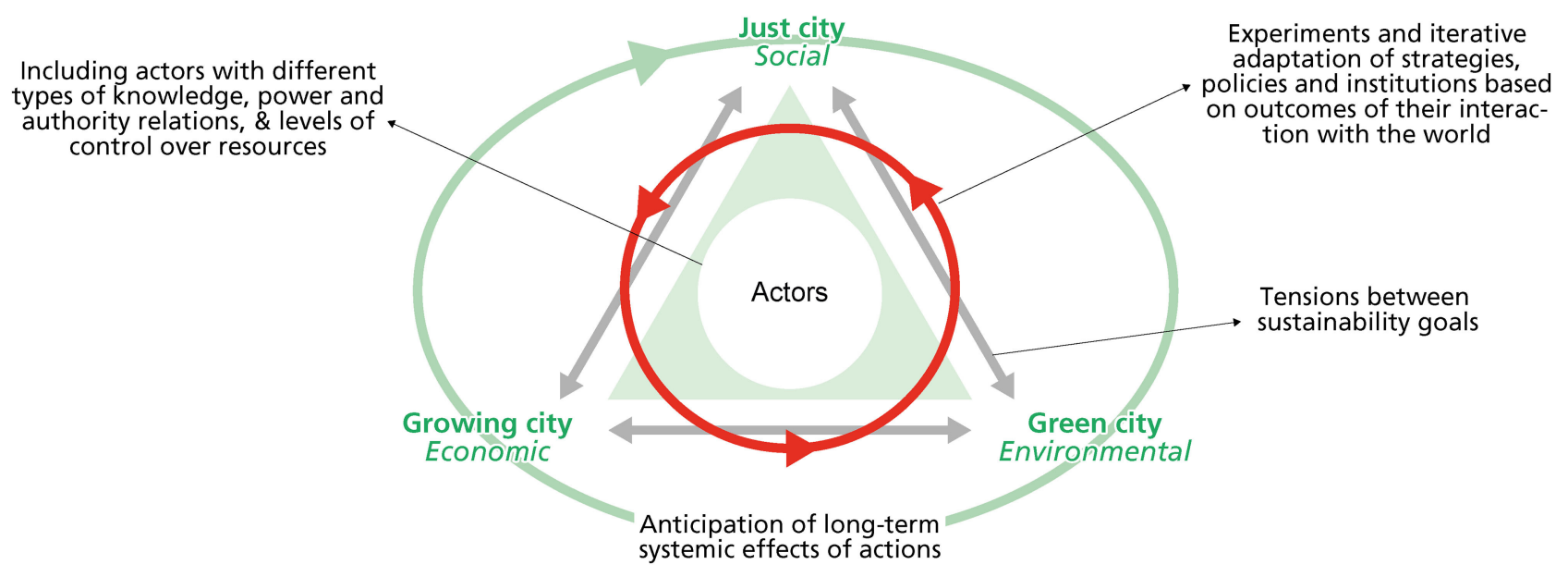

FIGURE 1 | System analysis in reflexive governance. The system analysis component of the analytical framework for reflexive governance broken down into its three subcomponents: (i) transdisciplinary knowledge development; (ii) experiments and adaptivity of strategies, and policies, and institutions; and (iii) anticipation of long-term systemic effects.

\section{Food for Good (Utrecht, The Netherlands) System Analysis}

\section{Transdisciplinary Knowledge Development}

Food for Good is a social care garden that emerged out of a partnership between the social care provider Stadsbrug, environmental foundation Eilandsteede, and a social entrepreneur from De Wending with experience of setting up social impact gardens and care farms. Together they developed the idea for a new food garden in Utrecht with the aim to provide social care and environmental education to vulnerable people. To facilitate access by vulnerable people, the social care garden was situated within a socioeconomically disadvantaged neighborhood in Utrecht. In addition to providing care, the ambition was to create a thriving ecosystem for local wildlife by applying organic gardening principles and nature-inclusive site management.

During the stage of project development, the three founding partners shared and integrated different types of knowledge, varying from expertise on organic horticulture to social care provision, environmental education, and sustainable entrepreneurship. Although Stadsbrug and Eilandsteede pulled out of the project 3 years later when it turned out that the local community would not take over the management responsibility for the garden, Food for Good continues to provide social care and environmental education by subcontracting these activities to professionals. The project is highly successful-they won three awards with associated money prizes, were mentioned as best-practice example in the mayor's New Year speech, and are regularly visited by professional delegations from across the world. In summary, the project mobilizes knowledge from different professional disciplines to create an opportunity for vulnerable people such as people with a history of substance abuse to participate in green space activities as part of their treatment plan.
Experiments and Adaptivity of Strategies and Institutions The initiative has initiated a number of experiments, while it can also be considered an experiment in its own right-it is one of the few urban gardens with an explicit social care purpose in Utrecht. The initiative contributes to addressing urban sustainability challenges such as inclusive access to green spaces, supporting urban biodiversity, providing healthy and affordable food, and reducing the carbon footprint of the city. Taking the position that in this particular case the NBS is an experiment in its own right, the analysis of reflexivity has focused on the institutional context of this initiative, particularly Utrecht municipality.

Food for Good is aiming to maintain a close working relationship with Utrecht municipality. The Food for Good coordinator considers it "basically his job" to contact and lobby different municipal departments and local politicians to access information, obtain necessary permits, and make the case for ongoing project funding. In response, Utrecht municipality provided a start-up subsidy, free-of-charge waste collection, street clean-ups, and some green space maintenance services, while also permitting the initiative to use and develop the garden on public land, provided they meet the conditions of the use agreement.

The municipality has to some extent flexibly responded to the requests made by the garden's coordinator for financial support. In recent years, structural funding has been provided through a fixed annual subsidy to support the social care function of the garden. In addition, the Work and Income Department is funding skill development activities for unemployed people provided by Food for Good on a per-client basis. This was only made possible after national government devolved responsibilities for social care, youth welfare, and occupational reintegration to municipalities, while also deinstitutionalizing the market, creating an opening for smaller-scale organizations like Food for Good to offer paid services in these domains. Food 
for Good's funding arrangement with cofunding by the social domain of the municipality for an urban NBSs provides a unique setup within the city.

Despite the support received and the adaptivity of the municipality, Food for Good is struggling to generate sufficient funding to continue the provision of a professional social care service through gardening practice. This resulted in the expenditure of considerable effort on applying to external project-based funding:

"They call it the project-carrousel-you always have to come up with something new to get funding. Projects that are already up and running and have proven their importance-you won't get funding for these. So we just keep on inventing events, projects, you name it. Projects for the elderly, for Moroccan women, for Moroccan men, building a bridge, digging a tunnel, making a passageway. At the moment we're setting up an alternative sustainability currency. Every time we just come up with a new project to get funding" (Project coordinator, Food for Good, 2017).

This state-of-affairs calls for even greater institutional adaptivity in order for Food for Good to maintain operability. For example, Food for Good has requested the municipality to be flexible in providing a permit for the sale of food and beverages to garden visitors. Utrecht municipality recognizes the value of Food for Good and therefore recently initiated a "learning experiment." This will engage three relevant sustainability initiatives, including Food for Good, and city officials in a dialogue about the value of multifunctional sustainability initiatives in the city and how to better support these, e.g., by adapting regulation influencing the operations of an initiative:

"Our struggle is that our budgets are linked to strategic policy programs [within the municipality], and these can be spent on initiatives meeting these programs. However, these do not operate in an integral way. [The learning experiment serves to explore] how you can organize an integrated approach within the municipality, to prevent an initiative of this kind from "drowning" into a continuous dialogue of subsidy requests and justifications, so it can instead focus on what's really important. We genuinely need to create more flexibility in the municipal budgets, but also in our sense of duty, our way of thinking." (Community liaison manager, Utrecht municipality, 2017).

"The alderman said, 'Now we will turn things around for a change. Rather than you having to find all the different entry points into the municipal organization, all of us [the relevant people within the municipality] will stand around the initiative and give a verdict on how valuable we think this initiative is and if we will pay for it.' If they don't pay, or only little, it still ends, it won't be sustainable, unless they provide lots of opportunities for [on-site] entrepreneurship." (Project coordinator, Food for Good, 2017).

It can be inferred from this that the municipality has been responding adaptively through the amendment of policies influencing this initiative. This has happened continuously over time, resulting in an ever more intricate working relationship between Food for Good and municipality, without any attempt by the latter to co-opt the initiative into a government agenda. Although initially not committed to active monitoring and learning, the learning experiment demonstrates a clear commitment of the municipality to make Food for Good an experiment to be cherished, nurtured, and drawn inspiration from. However, this progress would not have been made without a prolonged period of intensive lobbying by the project coordinator of the NBSs.

\section{Anticipation of Long-Term Systemic Effects of Action Strategies}

From the beginning, Food for Good showcased a strong awareness of how their initiative might interact with the coupled social, ecological, and technological systems at the scale of the city. With the deliberative goal of supporting societal (re)integration of vulnerable people through guided gardening practice, they situated the garden in one of the most socioeconomically deprived parts of the city with relatively high levels of unemployment, antisocial behavior, health deprivation, and people with a migration background. The garden seeks to engage immigrants lacking Dutch language skills, elderly in nearby care homes, people suffering from substance abuse or mental health issues, ex-inmates, homeless people, young people from special needs schools, and people with poor employment prospects. In addition to supporting vulnerable people, the garden contributes to biodiversity, healthy food provision, neighborhood attractiveness, and social cohesion, while also providing local jobs. The initiative sought to set themselves apart from other community gardens in Utrecht, which tend to be situated in more affluent districts and are run largely by, and for, residents with medium to high socioeconomic status.

\section{Goal Formulation}

The key actors involved in setting the main goal of creating a garden to support vulnerable people were the three founding organizations: Foundation De Wending, together with care provider Stadsbrug and environmental foundation Eilandsteede. Day-to-day decisions are made by the professional head gardener and the rehabilitation program officer. Gardeners are consulted on decisions around what to grow and what activities to organize and generally only participate in those activities for which they are motivated. They are not contributing to management decisions-service users visit the garden to be physically active and outdoors in nature and interact with others.

Although the overarching goal of the garden has remained stable over time, the projects and operations through which the initiative seeks to achieve this have changed to some extent. Notably, one of the initial objectives was to build, connect, and mobilize local citizens so that these could take on garden coordination after a 3-year start-up period. However, this ambition was dropped after the garden coordinator grasped the complexities of professionally supporting vulnerable people based on social care contracts. Added to this, they also realized there was a risk of citizens not maintaining commitment to the social care function of the garden, which would threaten or potentially even reverse contributions to social justice. This 
is also one of the main reasons for why engagement with local citizens, beyond the vulnerable people with support needs served by the initiative, is relatively limited. In summary, goals have been formulated in an iterative way between the parties formally involved in garden coordination. Participation in goal setting for the initiative as a whole is limited, which is done deliberately to uphold the social care function of the garden.

\section{Strategy Implementation}

The actors involved in goal setting also contributed to strategy implementation in the case of Food for Good. Strategy implementation was interactive, even after two out of three founding partners pulled out of the project in 2015. To continue accessing the knowledge and skills required for professionally running a social care garden, the garden coordinator hired freelance staff to operate the garden and manage client contracts with care providers. The garden coordinator is primarily focused on fundraising to generate income.

Concerning the resourcing of the garden, key in-kind contributions are provided by the service users and volunteers in garden maintenance. Project-based grants continue to make up an important source of funding. Income is also increasingly accrued from supporting clients with referrals made by social care organizations and Utrecht municipality. The garden also sells produce to local restaurants, garden visitors, and a food cooperative. The ongoing involvement of actors with different disciplinary backgrounds committed to urban sustainability has resulted in new activities such as producing biogas out of stale bread, collected from the neighborhood, and growing edible fungi on coffee grounds. In addition, the garden has developed a working relationship with local food banks to which they donate produce and started a beekeeping project to produce local honey. By championing creativity, diversity, and enterprise around urban transformation within a relaxed and non-judgmental setting, Food for Good has grown into one of the key players of the city's social justice and sustainable development movement. This is helping to further increase the adaptiveness of Utrecht municipality to this initiative.

\section{Koggen Green Roof (Malmö, Sweden) System Analysis}

\section{Transdisciplinary Knowledge Development}

Koggen is a green-roofed building compound located within Malmö's affluent neighborhood of Western Harbor (Västra Hamnen). As part of the municipality-led BiodiverCity Program (2011-2018), the municipal housing company and real estate owner MKB (Malmö Kommunala Bostadsbolag) committed to develop a new type of intensive green roof with low maintenance requirements. Intensive green roofs, as opposed to extensive or moss green roofs, have a deeper soil substrate to allow for more and a larger variety of vegetation. The Koggen green roof was implemented in 2014, and its performance was monitored subsequently. Under the BiodiverCity Program, more than 30 NBSs were implemented across the city. The aim of the program was to develop cost-effective products, services, and processes to facilitate the integration of ecological knowledge and experience into building practices, real estate management, and urban planning.

"As an ecologist, I also think the competences within the planning systems are not right-you have architects and planners, and they don't know a lot, if anything, about NBSs and ecosystem services. Same with engineers. Ecologists tend to work with nature conservation and nature conservation plans, but [they are] not involved in the planning process-[it is] a mistake." (Program leader, Malmö City, 2016).

The first ideas for a new intensive green roof project in Malmö were already formulated around the period of developing Malmö's Bo01 sustainable city district, which was part of the 2001 European Housing Fair. Some of these ideas subsequently became part of institutional frames, e.g., the Living-Building Dialogue and the Environmental Building Program South, which opened up space for more experimentation with structural greening. The Koggen green roof experiment involved the real estate company $(\mathrm{MKB})$ that had originally been part of the hybrid public-private networks involved in Bo01, a building developer open to new ideas, along with actors with expertise in ecology. These included landscape architects and designers (C Stad \& Landskap, VegTech), research institutes (Scandinavian Green Roof Institute-SGRI, Agricultural University of Sweden-SLU), and the municipality (Malmö City Environmental Department).

The project strongly emphasizes the economic and environmental pillars of sustainability while the social pillar is not clearly prioritized. It provides a best-practice example in the mobilization of place-specific expertise in ecology. However, other forms of local knowledge were not accessed-there was a lack of civic participation in the project:

"...we have not engaged citizens in new developments; there were no citizens directly in place. But all the developers were very much interested in the end-users' perspectives and they were guessing all the time whether end-users would appreciate this or that" (Program leader, Malmö City, 2017).

\section{Experiments and Adaptivity of Strategies and Institutions}

The Koggen project provided space for experimentation by different actors together sharing the ambition of better integrating ecological competence into the construction sector:

"They [building developers] were very enthusiastic; they wanted to do something different from business-as-usual" (Program leader, Malmö City, 2017).

Involved landscaping firms, for example, tested the impacts of different types of soil and vegetation and adapted their approaches based on recommendations by ecologists based at research institutes and the municipality. Likewise, the real estate company MKB experimented with different approaches to the maintenance of intensive green roofs. The Scandinavian Green Roof Institute carried out monitoring and maintenance activities over the 2016-2019 period.

The evaluation of the BiodiverCity program (IVL, 2018) showed long-term positive results on working practices in the development sector, as reflected in new skills and competencies 
by the different actors involved. The project also influenced institutional logics. For example, the Comprehensive Plan of Malmö City (Malmö City, 2014) for the first time prioritized the development of greener, healthier, more attractive, and more biodiverse urban environments, which is in line with the ambitions of the BiodiverCity Program. BiodiverCity has also shaped aspects of other environmental urban plans, such as the Cloudburst Plan (2017) and the Tree Strategy (under development):

"Planning with green and blue infrastructure are becoming a more and more accepted and popular concept among consultants and architects, which might slowly lead to a shift in city planning" (Program leader, Malmö City, 2017).

\section{Anticipation of Long-Term Systemic Effects of Action Strategies}

The BiodiverCity Program was implemented to achieve longterm systemic change as evidenced by the ambition to go beyond site-specific experiments through collating and sharing lessons with the development industry more broadly. Indeed, the results of monitoring demonstrated an increase of biodiversity at the Koggen site over the 2016-2019 period. However, end-users were not engaged in the project, which indicates a limited anticipation of how the new nature-based innovation interacts with the social system. The Koggen experiment was carried out in an affluent part of town, potentially increasing environmental injustices at the city level. However, this has likely been balanced by other projects carried out as part of BiodiverCity Program that targeted socioeconomically disadvantaged areas. Moreover, it could be anticipated that the central role of the municipal housing provider MKB in the Koggen experiment is likely to improve the uptake of intensive green roofs in areas with vulnerable communities (e.g., elderly people, people with immigrant background) in due course. That is, MKB owns approximately one-third of the rental apartments in Malmö and plays an important role in new construction commissioning, redevelopments, negotiating the maximum rental fee levels, and providing affordable housing for low-income households. Additionally, showcases such as Koggen are important in influencing other actors in the urban development domain, which is characterized by risk aversiveness regarding alternative green technologies. Lessons from Koggen have been shared through different learning channels (e.g., study visits, reports, handbook), which is likely to inspire the development of costeffective intensive green roofs elsewhere.

\section{Goal Formulation}

The overarching goal of the BiodiverCity Program was formulated together with project partners and in line with requirements of funding bodies. The domain-specific working groups of the program (e.g., green roofs and walls) consisted of representatives from different municipal departments, the regional government, universities, research institutes, construction and real estate companies, consultants, manufacturers, and contractors. For individual projects like Koggen, context-specific aims and objectives were formulated by the actors involved based on available competences. The aim of the Koggen green roof project was to utilize the largely unused space on Koggen's rooftop for creating a landscape continuum (i.e., mimicking the flora in the nearby coastal landscape), while experimenting with rooftop biotopes to enhance aesthetics, customer value through improving residents' views, and support biodiversity. It is also an experiment with intensive green roofsexploring the opportunities to increase the value compared to extensive green roofs. Intensive green roof experimentation sparked an iterative process of formulating additional objectives such as the need to document the maintenance needs of the site and plants. This was done in a participatory way involving both the actors involved in goal formulation and implementation of the green roof. As indicated previously, there was no attempt to directly engage with the views and values of the actual beneficiaries, i.e., citizens and future tenants. Their views were only indirectly represented through the housing company's previous experience with (surveying) their tenants.

\section{Strategy Implementation}

Actors with knowledge from different disciplines worked together, acting as critical friends, to realize the Koggen project. The BiodiverCity Program, including Koggen, was funded for $50 \%$ by Vinnova (Sweden's Innovation Agency), with the remainder contributed by the other involved partners. This funding model facilitated the representation of different views and interests in the implementation process.

The BiodiverCity program ultimately aimed to bring about a transition to a more nature-based urban society. To facilitate this, a three-step approach to implementing Koggen and other projects was taken. In the first step feasibility studies were carried out. Next, experiments were initiated and carefully monitored. Finally, lessons based on the previous two stages were identified and disseminated. This was done through a handbook on urban greening for healthy and biodiverse cities (Vinnova, 2017). The handbook aims to educate stakeholders on lowmaintenance urban nature and related business opportunities. All project partners from various disciplines were involved and contributed with relevant knowledge to the process of creating this handbook. In addition, a site-specific maintenance manual for durable biotope roofs was prepared on the basis of lessons from the Koggen experiment (Slagstedt et al., 2014; Fransson and Malmberg, 2018).

\section{Kamagawa Vision (Utsunomiya, Japan) System Analysis \\ Transdisciplinary Knowledge Development}

Initiated and led by the common-interest association "Nurturing Kamagawa," multiple actors contribute their knowledge and ideas to a new vision for the revitalization of Utsunomiya's downtown area-Kamagawa Vision. This marks a move away from dominant top-down and often disintegrated approaches from the past. Kamagawa Vision brings together citizens, the city administration, non-profit organizations (NPOs), businesses, and research institutes. As such, it integrates local knowledge with professional expertise in architecture, urban planning, water flows in urban drainage, landscape architecture, community 
building, ecology, and environmental education. Although the vision has a strong focus on economic development, it also touches upon the need to improve and raise awareness about the natural qualities of the heavily engineered Kamagawa river. The document identifies opportunities for creating a sense of place, improved social integration and environmental education, as it introduces some elements of the rich regional ecosystem into the urban space.

"There have been many beautification projects going on since the restoration of the river in 1982, but only the projects run by 'Nurturing Kamagawa' intend to educate citizens about the "real" nature of the river, its history, etc." (Hirose et al., 2018).

The Kamagawa Vision (2019) emerged from an architectgraduate's master's and $\mathrm{PhD}$ studies on vacant space challenges. Like most of the regional cities in Japan, Utsunomiya suffers from hollowing-out-the number of housing vacancies in the city center is growing, economic activities are declining along with the number of visitors, and the old-age dependency ratio is increasing (Utsunomiya City, 2010). Addressing some of these challenges, he initiated the Kamagawa Pocket (2013) — a platform for cocreation and social activities for sustainable neighborhood development. This platform provided the foundations for the association "Nurturing Kamagawa" (2017), its activities and the "Kamagawa Vision." The vision was also informed by past and current community-driven activities as part of the "Machizukuri Urban Planning Approach," which aimed to integrate community-based processes into top-down city planning. This was achieved through collaborative activities, such as plantings and clean-ups, whereby local residents and local governments worked together to improve livability (Ono 2017; Evans 2002: 447). Since 2004, for instance, the upgrading team of Utsunomiya Machizukuri Suishin Kiko NPO (Institute for Town Planning Promotion), a publicprivate partnership for promoting revitalization of the city center, has been organizing seasonal flower-planting along the river's $3-\mathrm{km}$ downtown promenade with the involvement of elderly groups and students from the neighboring schools. Other community-based organizations, such as the resident association and the Machizukuri Center, have also been involved in beautification activities. Most of these activities are funded through different departments of the city administration, while there are also membership contributions by local businesses.

\section{Experiments and Adaptivity of Strategies and Institutions}

Responding to the devastating flood event in 1982 and taking into account space limitations in the downtown area, Kamagawa was reconstructed as the first double-layered river in Japan. The river is divided into two channels-the upper channel was placed above the natural channel, situated underground, using highly engineered concrete structures. The lower river layer qualifies as first-class river and therefore remains under national jurisdiction (River Law, 1967). This is unlike the upper layer in the downtown area, which is managed by the city administration in collaboration with different NPOs.
"It could be said that the top layer of the river is deregulated, so that many sectors could join the improvement of the river" (NPO representative, 2020).

The Kamagawa Vision seeks to exploit this opportunity by introducing more flexibility and space for a variety of actors to interactively engage with the urban waterscape, the river's natural and cultural qualities and its sources and ecology. It strives for community building through "creating a common vision, and a mindset through education, involvement and information" (Nurturing Kamagawa representative, 2020). Addressing the shortcomings of historic top-down revitalization efforts in which the neighborhood's natural qualities were hardly taken into account, Kamagawa Vision is tapping into the landscape formation principles of the Landscape Act (June 2005), which promotes a system understanding in which humans and nature are intricately connected:

"a good landscape is formed by harmonizing the nature, history, and culture of the area with people's lives and economic activities, the development and preservation of the landscape shall be promoted through land use" (Landscape Plan, Utsunomiya City, 2008, p. 1).

The initiator of the visioning activities has been in continuous dialogue with the municipality to make the case for a more community-driven revitalization effort along with an iterative planning process and reliable funding for these activities. Some municipal departments showed an interest in actively participating in the visioning process to support more reflexive ways of working, whereas others did not. The Landscape and the Regional Policy Departments were most clearly involved-they contributed to the visioning process and supported some related activities. However, since 2019, the Landscape Department is no longer supporting work on the concept, which means that the Regional Policy Department is currently the only department directly funding the vision. The Urban Development Department indirectly contributes to Kamagawa Vision through supporting Utsunomiya Machizukuri Suishin Kiko NPO, although not specifically to support the river restoration project. Interestingly, the city's Community Building Department, which is indirectly financing the Machizukuri Center and as such community-based activities, has not been involved in the Kamagawa Vision and related activities organized by Nurturing Kamagawa.

The fact that only certain municipal departments have shown an interest in supporting a more participatory approach to urban development and the lack of cross-departmental collaboration on the topic of urban nature is likely to obstruct future policy development in this field. The lack of reflexive engagement by a number of relevant municipal departments limits opportunities for Kamagawa Vision to contribute to more and higher-quality nature in the city's downtown area.

\section{Anticipation of Long-Term Systemic Effects of Action Strategies}

The Kamagawa Vision has brought together previously disconcerted efforts by the local administration, non-profit organizations, academia, and residents to support the area's 
multifaceted revitalization. By building upon principles of the Landscape Act, it seeks to reconnect people with their natural environment. This is expected to increase urban sustainability as reflected in an improved living environment, economic regeneration, an improved sense of place, and enhanced environmental awareness. Importantly, it can also lead to a more just city by providing a platform for previously unheard voices, such as the neighborhood's elderly residents and students of the neighboring schools in urban visioning processes. The novel community engagement processes in urban planning could arguably also motivate the development of more participatory governance processes in other parts of the city. In the long term, continuous engagement with the riverscape is envisaged to improve nature conservation and support biodiversity of endangered species in the river.

Despite these positive effects on urban sustainability in downtown Utsunomiya, it is unlikely that such effects will prove to be of a systemic nature if the powerful actors resourcing the visioning process and urban renewal do not take a more reflexive stance toward the input of the NPOs, citizens and citizen groups, and researchers involved, for example, by aiming to bridge municipal silos. This is needed to guarantee a longterm and broadly shared vision of a more nature-based city (i.e., nature-based thinking). Among other ends, this may contribute to addressing some of the potentially negative long-term effects associated with the aim of Nurturing Kamagawa to upgrade vacant buildings and find new functions for these, such as the potential gentrification of today's declining neighborhood.

\section{Goal Formulation}

The aim of Nurturing Kamagawa is to create social cohesion and empower citizens through different, often demand-driven, community projects around exploring, learning about, and enhancing the natural qualities of the river and its surroundings. The environmental visioning and designing activities that are organized by Nurturing Kamagawa as part of the Kamagawa Vision provide the first attempts toward a more inclusive and reflexive goal formulation in the strategy supporting the neighborhood's revitalization. In this process, the broader goal of community-driven neighborhood development has not changed over time, while the means of how to achieve it have been continuously reformulated. An example of a community-based activity that contributed to shape revitalization goals is the "content-based urban landscape formation" exercise with the aim to integrate nature into urban revitalization plans. During this activity, residents and students worked together on planning the future cityscape around the Kamagawa river through the (re)interpretation of "landscape principles" and "landscape contents" as they are outlined in the 2004 Landscape Act (Hirose et al., 2018). This exercise provided space for discussion about natural, climatic, cultural, and livelihood-related aspects of the environment, which had initially been overlooked in the vision-given a strong emphasis on economic growth and renovating the built fabric. This reflection was very much needed because the meaning and means of revitalization have previously taken different shapes and forms depending on the actor formulating the goals. For instance, the local government has been emphasizing the importance of increased economic activity, while different NPOs rather focused on improving the living environment, community mobilization, and the aesthetic experience (Kiko, 2020).

\section{Strategy Implementation}

Kamagawa Vision purposefully brings together actors holding knowledge and resources essential for the revitalization of the downtown area. This has led to the formation of "Nurturing Kamagawa," a common-interest group comprising students, residents, landowners, and experts, who are organizing dialogues on the future sustainable development of the neighborhood. The development of Kamagawa Vision is based on an ongoing iterative visioning process organized by this group, which encompasses symposia, design classes, and activities aimed at awareness raising and environmental education. This process serves to engage additional actors, including vulnerable groups such as elderly people, along with young people, non-profit organizations, businesses, researchers, and representatives from different municipal departments. These actors have been actively collaborating to gain a shared understanding of the values and the potential of the Kamagawa river and its surrounding downtown neighborhood.

"By building up the projects step-by-step, we hope to gradually create a landscape that people will love and feel more attached to, and that people who have not yet visited the site will come and see it at least once." (Nurturing Kamagawa representative, 2020).

Although this process is enhancing the quality of nature in the riverscape, it does not necessarily increase the quantity of nature. Related to this, there is also a risk that current understandings of "Nature-Based Thinking" are still fragmented and will not result in a comprehensive urban vision on how to improve urban nature to the benefit of sustainable and just cities.

At this point, Kamagawa Vision has not yet brought significant physical changes to the cityscape. However, at least one department in the city administration is receptive to the approach of Kamagawa Vision to community-driven revitalization, resulting in the allocation of funding to support future activities. Activity-based grants, both from local and national governmental sources, continue to be an important source of income, which creates a dependency on these powerful actors. Although developed with the aim to eventually inspire more integrated working between multiple disciplines, not the least within the municipality, the Kamagawa Vision has not yet informed formal city-wide policies.

\section{DISCUSSION}

The present study researched the potential of reflexive governance for contributing to more sustainable and just cities using a framework by Voß and Kemp (2006), adapted with guiding questions, comprising three main components: (I) system analysis, (II) goal formulation, and (III) strategy implementation. To this end, we selected three case studies with evidence of reflexive governance based on the engagement 
TABLE 2 | Overview showing the main positive (+) and negative (-) outcomes of reflexive governance on just and sustainable cities for each of the three studied cases.

\section{Case} Outcomes

Food for Good (Utrecht, The Netherlands)

Koggen green roof (Malmö, Sweden)

Kamagawa Vision (Utsunomiya, Japan)

of diverse actors from different disciplinary and epistemic backgrounds in iterative process of developing an urban NBS. In Table 2, we provide an overview of the main promises and pitfalls of the three case studies, which we subsequently discuss below.

The analysis of these cases demonstrates efforts at system analysis and subsequent goal setting and strategy implementation to address systemic problems. This resulted in the formulation of goals around, e.g., improving access to healthy food, quality of life, job skills training, climate adaptation, and biodiversity. In response to this, professionals from different disciplines engaged in a process of joint experimentation-to some extent also mobilizing non-expert interests and beliefs. This resulted in sustainability gains in all three cases while there were also attempts to scale out lessons learned from these initiatives in the Food for Good and Koggen green roof cases to other initiatives and neighborhoods. This reflects an ambition in all cases to contribute to urban transformation-radical change across multiple dimensions of urban living (McCormick et al., 2013).

We found that goals around improving justice and the inclusion of diverse voices were included in the Food for Good and Kamagawa Vision cases. This was particularly prioritized in Food for Good through the deliberate engagement of vulnerable people with support needs in the social care garden. However, there was a lack of explicit consideration of potentially negative effects on distributional justice (Anguelovski et al., 2018)gentrification was highlighted as a risk of revitalization efforts in the Koggen green roof and Kamagawa Vision initiatives, and this was not clearly accounted for in the planning of these projects. At the same time, we argue for caution in making strong statements about justice implications given the complex interactions between sociotechnical and socioecological systems within urban contexts (Wolfram and Frantzeskaki, 2016). For example, although the Koggen green roof case was carried out in an affluent district and therefore could be reinforcing gentrification processes locally, the central role played by the municipal housing provider MKB, owning approximately onethird of the city's housing stock, is likely to motivate more nature-based urban development practices in areas with high levels of social housing in due course. Moreover, the project's explicit focus on improving the business case for extensive green roofs and knowledge dissemination to the sector as a whole is expected to motivate the rolling-out of nature-inclusive urban development practices to other actors in the sector as well.

In addition to addressing systemic sustainability challenges, we also observed evidence for the studied initiatives challenging existing technocratic, centralized, and inflexible governance arrangements influencing urban development. In all three projects, goals were developed involving the same actors that had also been involved in system analysis. There was scope for critically discussing and adapting objectives over various stages of the implementation process in iterative ways, taking into account new knowledge emerging from experimentation or emerging funding opportunities. The overarching goals of the projects, however, remained stable over time. With initiatives establishing themselves and monitoring and demonstrating a positive contribution to urban sustainability, they can begin to challenge and influence powerful actors outside the boundaries of the place-specific experiment. In the Food for Good case, this resulted in a unique setup where the municipality is cofunding a nature-based initiative through social, rather than fully through environmental, budgets. Moreover, the municipality showed a preparedness to critically evaluate and possibly improve their structural support mechanisms for social-impact grassroots initiatives. Such outcomes are suggestive of Nature-Based Thinking (Randrup et al., 2020), where different departments acknowledge the intricate relationship between people, nature, and economy, and work together by, e.g., developing shared visions to ensure the improved integration of nature into the 
urban fabric. This also suggests that reflexivity can extend beyond the actors involved in a particular experiment to involve regime, i.e., system-level, actors, effectively taking place both within and beyond a single initiative, as also illustrated in Figure 2.

Despite the largely positive effects on sustainable and just cities, each of the cases ostensibly also revealed areas for improvement (Table 2). This included addressing the lack of explicit concern for distributional justice, discussed previously, but also overcoming issues around limited citizen participation in the Food for Good and Koggen green roof cases (i.e., procedural injustice). A third area for improvement specific to the Kamagawa Vision case was the need to improve the efficacy of shaping the practices of powerful actors beyond those directly involved in the initiative. This would enable a better integration of the voices of different sociocultural groups and marginalized disciplines, e.g., landscape architecture, into urban planning (i.e., recognition injustice).

Notably, our analysis showed that most of the identified areas for improvement were unrelated to the quality of reflexive governance processes within the studied cases. Instead, these resulted from ongoing power struggles between the studied initiative and regime actors and institutions determining the bandwidth in which the initiative could freely operate (Figure 2). The degree to which dominant actors and institutions flexibly responded to initiatives was partially context-specific, which we illustrate below. This sets apart the studied initiatives from many other coproduction efforts for sustainability-characterized as depoliticized and isolated efforts that avoid engagement with dominant power structures (Turnhout et al., 2020). However, the present findings suggest that attempts to loosen and open up system boundaries are not always successful and may be a matter of a long-term laborious effort. This is in line with research suggesting that attempts at urban transformation are often contested and require the long-term engagement of actors (Stripple and Bulkeley, 2019).

We observed at least three different examples of power struggles between the studied initiatives and system structures. First, there were power struggles between different types of knowledge-or epistemic logics-for dominance in urban planning. This resulted, for example, in the deliberate exclusion of powerful municipal departments from the Koggen green roof case, and the BiodiverCity program more broadly, to enlarge the influence of ecological knowledge on urban development. This was done to avoid the prioritization of technological innovation

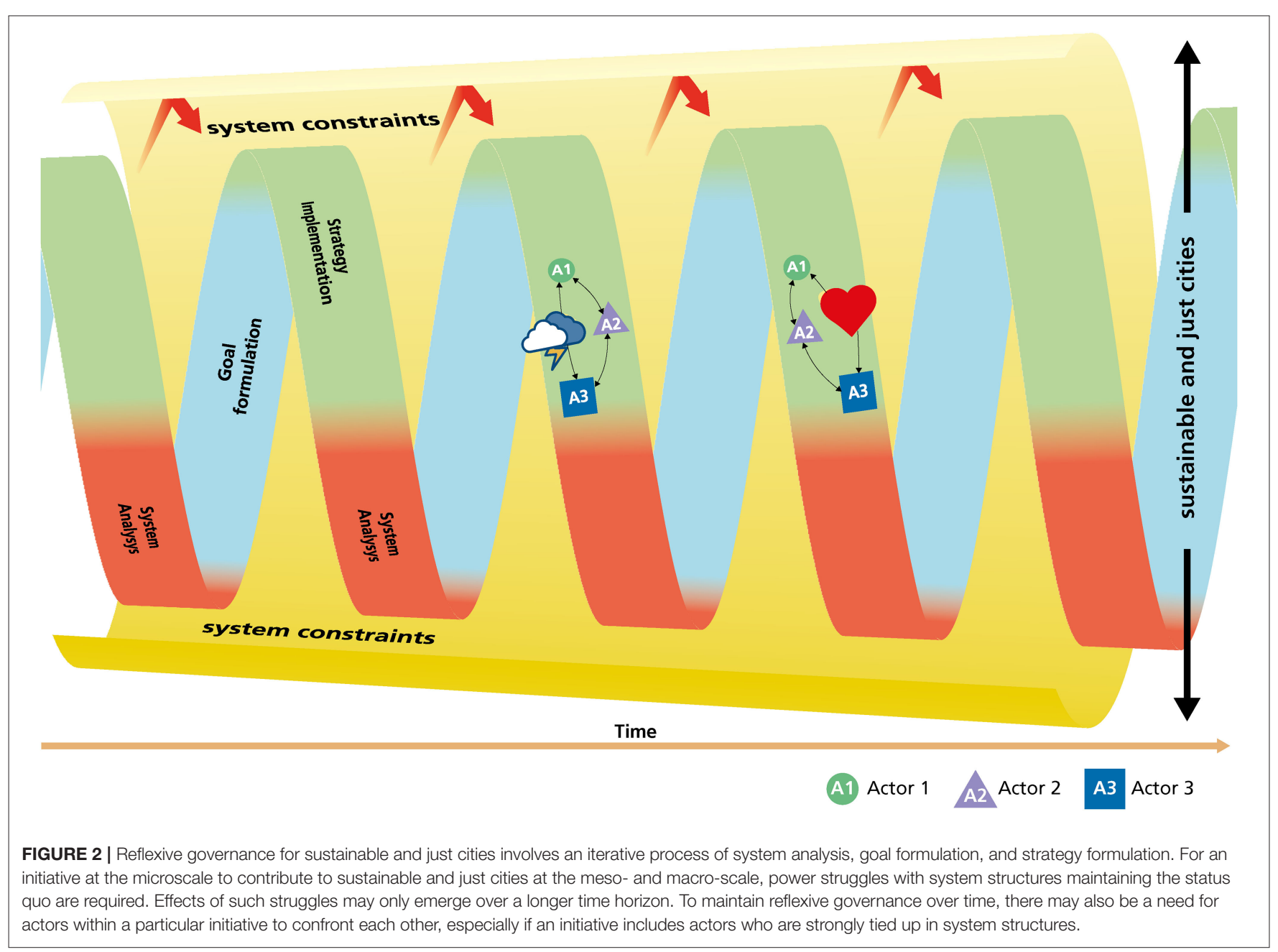


over nature-based innovation for increased sustainability. Second, power struggles surfaced between actors with different levels of resources and capacities. In the Food for Good case, this led to the decision to restrict participation by local residents. This was motivated by a fear for ordinary residents-the "good" citizens who act reliably in line with dominant top-down rationalities (van Dam et al., 2015) - dispelling exactly those vulnerable people with support needs that the initiative was seeking to empower.

A third power struggle revolved around conflicting ontologies, i.e., the question of "what constitutes 'the urban"” (Walker, 2015, p. 185)? At its core are discordant perspectives on cities as exclusively sociotechnical systems or as coupled sociotechnical and socioecological systems. This conflict was surfacing in the Kamagawa Vision case where technocratic approaches to urban regeneration through investment in gray infrastructure are clashing with a civic group's proposal to also consider strengthening human-environment interactions for, e.g., an improved sense of place, participation of different groups in society, and improved ecosystem quality. The vision for urban regeneration bringing together different sociocultural communities, nature, and economic development is currently supported by only a single municipal department, which is limiting the impact of participation on urban development. The financial dependence of the citizen association on this same municipality has prompted a careful balancing act between two types of relationships. The first is in some aspects best characterized as a non-reflexive "fit and conform" relationship to ensure continuity in public funding (Smith and Raven, 2012). The second is best described as a "stretch and transform" relationship aimed at transforming the dominant perspective that urban regeneration can only be achieved through sociotechnical interventions. This is a challenging status quo-stretching "locked-in" system actors too much could easily lead them to withdraw from the discursive sphere (Sol et al., 2018), thwarting opportunities for meaningful change. Refraining from this could, however, turn NBSs into "nature-based debacles," where any progress on urban sustainability outcomes is made undone by increasing injustices (Toxopeus et al., 2020). In the other two cases, these struggles around urban ontologies were less profound or even absent given that at least some regime-level actor networks actively employed NBSs as strategies for healthy urbanization. This suggests that reflexive governance of NBSs for sustainable and just cities needs to set very different priorities and timescales, with a very different bandwidth of possible outcomes, depending on sociopolitical context (e.g., northwest Europe compared to east Asia).

The present findings complement and add to existing literature on the politics of reflexive governance by showing that, although reflexive arrangements can be subject to disruption and domination by powerful actors and networks, the reverse may also apply. This happens when reflexivity is employed to coax these agents to change dominant working practices in a way that embraces a broader set of urban epistemologies and ontologies. Such processes, we argue, are most easily achieved by initiatives operating in "shadow coalitions" comprising representatives for disempowered disciplines, underrepresented sociocultural groups, or the less educated and wealthy. While engaging a diverse set of actors is the ultimate goal for sustainable and just cities, paradoxically the more powerful-including ordinary citizens in some case-are best excluded from the core of such processes. Over time, however, engagement with structures of power is needed to bring about a system change toward more sustainable and just cities. This can happen directly by confronting dominant actors with the consequences of businessas-usual, or indirectly. Examples of indirect engagement with dominant actors include the development of pilot projects and intensive monitoring of these, the demonstration of positive interactions between the green, growing, and just city and the sharing of codeveloped knowledge through, e.g., handbooks.

The present study also contributes to understanding of mosaic governance in which the question of how mutual learning between regime actors and civil society practices contributes to sustainable and just cities is not clearly addressed. Our findings demonstrate the need to understand these relationships as iterative, and the reflexive governance framework by Voß and Kemp (2006) - when analyzed through an urban justice lensprovides a suitable way to do so. The present study also sheds light on how bottom-up initiatives that are "sensitive to the diversity and dynamics of active citizenship" (Buijs et al., 2016b, p. 3) do not necessarily have to be started by members from the general public. In fact, processes serving the engagement of particular underrepresented groups or disciplines may in some cases best avoid their active engagement in decision-making processes. For that reason, we propose that a broader range of actors is considered in the study of how different communities are interacting in the development of urban nature for just and sustainability cities (i.e., mosaic governance).

\section{CONCLUSION}

Drawing on three international case studies in which actors are taking a reflexive approach to experimenting with urban NBSs, we analyzed long-term processes of reflexive governance for sustainable and just cities. This study departed from previous analyses of this concept by adding an explicit justice framing to the study of reflexivity along with a focus on shadow advocacy at the urban scale. Urban NBSs provided a research object par excellence given the present rhetoric heralding it as an innovation with potential to contribute to environmental, economic, and social pillars of sustainability simultaneously. However, it is also a type of innovation that does not sit well with dominant urban development practice in which risk avoidance and profit maximization are prime institutional logics.

We demonstrated how the development of urban NBSs for sustainable and just cities requires different types of actors to work together on innovative practices that depart from business-as-usual. Introducing reflexivity in these arrangements serves to protect NBSs from dominant interests with a narrow view on urban sustainability. At the same time, engagement with powerful actors (i.e., shadow advocacy) is required to improve the understanding and incorporation of "socionatural 
entanglements" (Heynen et al., 2006) in urban planning processes. We unveiled how this is creating tensions with the ambition of sustainable and just cities, for example, shunning public participation to empower underrepresented or suppressed voices (Food for Good and Koggen green roof cases), adopting elements of the economy-focused technocratic approach to urban regeneration (Kamagawa Vision case), or investing in NBSs in affluent as opposed to deprived neighborhoods (Koggen green roof case). On these grounds, it could be tempting to dismiss the studied cases as "nature-based debacles" co-opted by neoliberal agendas. The present research shows how such strong evaluations based on a set of preset criteria for justice are potentially unwarranted given that urban transformation is an ongoing process of contestation and struggle (Stripple and Bulkeley, 2019). It is only by taking a context-sensitive perspective and appreciating processes of reflexive governance across different scales and over a prolonged period of time that we can truly begin to appreciate the potential of NBSs for sustainable and just cities.

\section{DATA AVAILABILITY STATEMENT}

The raw data supporting the conclusions of this article will be made available by the authors, without undue reservation.

\section{ETHICS STATEMENT}

Ethical review and approval was not required for the study on human participants in accordance with the local legislation and institutional requirements. The patients/participants provided their written informed consent to participate in this study. Written informed consent was obtained from the individual(s) for the publication of any potentially identifiable images or data included in this article.

\section{REFERENCES}

Anguelovski, I., Connolly, J., and Brand, A. L. (2018). From landscapes of utopia to the margins of the green urban life. City 22, 417-436. doi: 10.1080/13604813.2018.1473126

Baldock, K. C. R., Goddard, M. A., Hicks, D. M., Kunin, W. E., Mitschunas, N., Osgathorpe, L. M., et al. (2015). Where is the UK's pollinator biodiversity? The importance of urban areas for flower-visiting insects. Proc. R. Soc. B Biol. Sci. 282:20142849. doi: 10.1098/rspb.201 4.2849

Botzat, A., Fischer, L. K., and Kowarik, I. (2016). Unexploited opportunities in understanding liveable and biodiverse cities. A review on urban biodiversity perception and valuation. Glob. Environ. Chang. 39, 220-233. doi: 10.1016/j.gloenvcha.2016. 04.008

Brown, R. R., Farrelly, M. A., and Loorbach, D. A. (2013). Actors working the institutions in sustainability transitions: the case of Melbourne's stormwater management. Glob. Environ. Chang. 23, 701-718. doi: 10.1016/j.gloenvcha.2013.02.013

Buijs, A., Elands, B., Havik, G., Ambrose-Oji, B., Geroházi, E., van der Jagt, A., et al. (2016a). Innovative Governance of Urban Green Spaces: Learning From 18 Innovative Examples Across Europe. EU FP7 Project GREEN SURGE (ENV.2013.6.2-5-603567), Deliverable 6.2. Copenhagen Available online at: http://greensurge.eu/working-packages/wp6/

\section{AUTHOR CONTRIBUTIONS}

AJ and BK: conceptualization, methodology, validation, formal analysis, investigation, data curation, writingoriginal draft, and writing-review and editing. $\mathrm{SH}$ and WT: investigation and writing-review and editing. All authors: contributed to the article and approved the submitted version.

\section{FUNDING}

This research has been funded by the European Commission's Horizon 2020 research and innovation program under grant agreement no. 730243, together with participating partners in the NATURVATION project and the International Research Fellowship Program of the Japan Society of the Promotion of Science.

\section{ACKNOWLEDGMENTS}

We thank Helen Toxopeus, Hens Runhaar, Attila Katona, and Natalie Gulsrud, along with two reviewers, for their reflections and feedback on previous versions of this paper. We are also grateful to colleagues in the NATURVATION project for supporting the development of the case study protocol and contributing to the data collection.

\section{SUPPLEMENTARY MATERIAL}

The Supplementary Material for this article can be found online at: https://www.frontiersin.org/articles/10.3389/frsc.2020. 583833/full\#supplementary-material

Buijs, A., Hansen, R., Van der Jagt, S., Ambrose-Oji, B., Elands, B., Lorance Rall, E., et al. (2018). Mosaic governance for urban green infrastructure: upscaling active citizenship from a local government perspective. Urban For. Urban Green. 40, 53-62. doi: 10.1016/j.ufug.2018.06.011

Buijs, A., Mattijssen, T. J., van der Jagt, A. P. N., Ambrose-Oji, B., Andersson, E., Elands, B. H., et al. (2016b). Active citizenship and the resilience of urban green: fostering the diversity and dynamics of citizen contributions through mosaic governance. Curr. Opin. Environ. Sustain. 22, 1-6. doi: 10.1016/j.cosust.2017.01.002

Buizer, M., Elands, B., and Vierikko, K. (2016). Governing cities reflexively-the biocultural diversity concept as an alternative to ecosystem services. Environ. Sci. Policy 62, 7-13. doi: 10.1016/j.envsci.2016.03.003

Bulkeley, H., and Castán Broto, V. (2013). Government by experiment? Global cities and the governing of climate change. Trans. Inst. Br. Geogr. 38, 361-375. doi: 10.1111/j.1475-5661.2012.00535.x

Bulkeley, H., Coenen, L., Frantzeskaki, N., Hartmann, C., Kronsell, A., Mai, L., et al. (2016). Urban living labs: governing urban sustainability transitions. Curr. Opin. Environ. Sustain. 22, 13-17. doi: 10.1016/j.cosust.2017.02.003

Bush, J., and Doyon, A. (2019). Building urban resilience with naturebased solutions: how can urban planning contribute? Cities 95:102483. doi: 10.1016/j.cities.2019.102483

Cleaver, F. (2002). Reinventing institutions: bricolage and the social embeddedness of natural resource management. Eur. J. Dev. Res. 14, 11-30. doi: $10.1080 / 714000425$ 
De Vries, S., van Dillen, S. M. E., Groenewegen, P. P., and Spreeuwenberg, P. (2013). Streetscape greenery and health: stress, social cohesion and physical activity as mediators. Soc. Sci. Med. 94, 26-33. doi: 10.1016/j.socscimed.2013.06.030

Dorst, H., van der Jagt, S., Raven, R., and Runhaar, H. (2019). Urban greening through Nature-Based Solutions - key characteristics of an emerging concept. Sustain. Cities Soc. 49:101620. doi: 10.1016/j.scs.2019.101620

Dougherty, D. (2017). Taking advantage of emergence for complex innovation eco-systems. J. Open Innov. Technol. Mark. Complex. 3:14. doi: 10.1186/s40852-017-0067-y

Driessen, P. P. J., Dieperink, C., van Laerhoven, F., Runhaar, H. A. C., and Vermeulen, W. J. V. (2012). Towards a conceptual framework for the study of shifts in modes of environmental governance - experiences from the Netherlands. Environ. Policy Gov. 22, 143-160. doi: 10.1002/eet.1580

Droste, N., Schröter-Schlaack, C., Hansjürgens, B., and Zimmermann, H. (2017). "Implementing nature-based solutions in urban areas: financing and governance aspects," in Nature-Based Solutions to Climate Change Adaptation in Urban Areas, eds N. Kabisch, H. Korn, J. Stadler, and A. Bonn (Cham: Springer), 307-321.

Dupras, J., Drouin, C., André, P., and Gonzalez, A. (2015). Towards the establishment of a green infrastructure in the region of montreal (Quebec, Canada). Plan. Pract. Res. 7459, 1-21. doi: 10.1080/02697459.2015.1058073

Elmqvist, T., Setälä, H., Handel, S. N., van der Ploeg, S., Aronson, J., Blignaut, J. N., et al. (2015). Benefits of restoring ecosystem services in urban areas. Curr. Opin. Environ. Sustain. 14, 101-108. doi: 10.1016/j.cosust.2015.05.001

European Commission (2015). Towards an EU Research and Innovation Policy Agenda for Nature-Based Solutions \& Re-Naturing Cities. Brussels. Available online at: http://bookshop.europa.eu/en/towards-an-eu-research-andinnovation-policy-agenda-for-nature-based-solutions-re-naturing-citiespbKI0215162/

Evans, J. P. (2011). Resilience, ecology and adaptation in the experimental city. Trans. Inst. Br. Geogr. 36, 223-237. doi: 10.1111/j.1475-5661.2010.00420.x

Fainstein, S. S. (2010). The Just City. Ithaka, NY: Cornell University Press.

Feindt, P. H., and Weiland, S. (2018). Reflexive governance: exploring the concept and assessing its critical potential for sustainable development. Introduction to the special issue. J. Environ. Policy Plan. 20, 661-674. doi: 10.1080/1523908X.2018.1532562

Fransson, A., and Malmberg, J. (2018). Biotoptaken på Koggen, delrapport \#2 Utvecklings- och åtgärdsrapport för säsongen 2017. En delrapport för uppföljning 2016 - 2019. [Koggen Biotope Roof - 2017 Annual Report. Part of the FollowUp Project 2016-2019]. Available online at: https://malmo.se/download/18. cb832751656711ccfb99c7/1535620939226/Rapport\%20SGRI\%20Koggens \%20Biotoptak\%202017.liten\%20fil_.pdf (accessed November 11, 2019).

Frantzeskaki, N. (2019). Seven lessons for planning nature-based solutions in cities. Environ. Sci. Policy 93, 101-111. doi: 10.1016/j.envsci.2018.12.033

Frantzeskaki, N., McPhearson, T., Collier, M. J., Kendal, D., Bulkeley, H., Dumitru, A., et al. (2019). Nature-based solutions for urban climate change adaptation: linking science, policy, and practice communities for evidence-based decisionmaking. BioScience, 69, 455-466. doi: 10.1093/biosci/biz042

Fraser, N. (2007). "Reframing justice in a globalizing world," in Global Inequality: Patterns and Explanations, eds D. Held and A. Kaya (Cambridge: Polity Press), 252-272.

Grin, J., Rotmans, J., and Schot, J. (2010). Transitions to Sustainable Development: New Directions in the Study of Long Term Transformative Change. Routledge.

Gulsrud, N. M., Hertzog, K., and Shears, I. (2018). Innovative urban forestry governance in Melbourne? Investigating "green placemaking" as a naturebased solution. Environ. Res. 161, 158158-167167. doi: 10.1016/j.envres.2017. 11.005

Gupta, J., Pahl-Wostl, C., and Zondervan, R. (2013). "Glocal” water governance: a multi-level challenge in the anthropocene. Curr. Opin. Environ. Sustain. 5, 573-580. doi: $10.1016 /$ j.cosust.2013.09.003

Haaland, C., and van den Bosch, C. K. (2015). Challenges and strategies for urban green-space planning in cities undergoing densification: a review. Urban For. Urban Green. 14, 760-771. doi: 10.1016/j.ufug.2015.07.009

Haase, D., Kabisch, S., Haase, A., Andersson, E., Banzhaf, E., Baró, F., et al. (2017). Greening cities - to be socially inclusive? About the alleged paradox of society and ecology in cities. Habitat Int. 64, 41-48. doi: 10.1016/j.habitatint.2017.04.005
Hajer, M., Nilsson, M., Raworth, K., Bakker, P., Berkhout, F., de Boer, Y., et al. (2015). Beyond cockpit-ism: four insights to enhance the transformative potential of the sustainable development goals. Sustainability 7, 1651-1660. doi: $10.3390 /$ su7021651

Hendriks, C. M., Dryzek, J. S., and Hunold, C. (2007). Turning up the heat: partisanship in deliberative innovation. Pol. Stud. 55, 362-383. doi: 10.1111/j.1467-9248.2007.00667.x

Hendriks, C. M., and Grin, J. (2007). Contextualizing reflexive governance: the politics of Dutch transitions to sustainability. J. Environ. Policy Plan. 9, 333-350. doi: 10.1080/15239080701622790

Heynen, N., Kaika, M., and Swyngedouw, E. (2006). In the Nature of Cities: The Politics of Urban Metabolism. London: Routledge.

Hirose, S., Nakamura, S., and Nakajima, H. (2018). Content-based urban landscape formation: a case of collaboration on landscape planning for the urban district around Kamagawa River, Utsunomiya City, Tochigi Prefecture. Presentation at the 3rd Kamagawa Vision Workshop (Utsunomiya).

Hodson, M., Geels, F. W., and McMeekin, A. (2017). Reconfiguring urban sustainability transitions, analysing multiplicity. Sustain. 9:299. doi: $10.3390 /$ su 9020299

Horst, M., McClintock, N., and Hoey, L. (2017). The intersection of planning, urban agriculture, and food justice: a review of the literature. J. Am. Plan. Assoc. 83, 277-295. doi: 10.1080/01944363.2017.1322914

Hysing, E. (2009). From government to governance? A comparison of environmental governing in Swedish forestry and transport. Governance 22, 647-672. doi: 10.1111/j.1468-0491.2009.01457.x

IVL (2018). Varför investera i gröna lösningar med hög biologisk mångfald? Vägledning för fastighetsägare och entreprenörer [Why to Invest in Green Solutions With Enhanced Biodiversity? Guide to Property Owners and Developers]. Nr B2297. Available online at: https://www.ivl.se/download/18. 2aa2697816097278807126f/1519639036557/B2297.pdf (November 11, 2019).

Kabisch, N., Frantzeskaki, N., Pauleit, S., Naumann, S., Davis, M., Artmann, M., et al. (2016). Nature-based solutions to climate change mitigation and adaptation in urban areas: perspectives on indicators, knowledge gaps, barriers, and opportunities for action. Ecol. Soc. 21:39. doi: 10.5751/ES-08373-210239

Kabisch, N., Korn, H., Stadler, J., and Bonn, A. (2017). Nature-Based Solutions to Climate Change Adaptation in Urban Areas: Linkages Between Science, Policy and Practice. Cham: Springer Nature.

Karvonen, A. (2018). “The city of permanent experiments?, in Innovating Climate Governance: Moving Beyond Experiments, eds B. Turnheim, P. Kivimaa, and F. Berkhout (Cambridge: Cambridge University Press), 201-215.

Kemp, R., and Loorbach, D. (2006). "Transition management: a reflexive governance approach," in Reflexive Governance for Sustainable Development, eds J. Voß, D. Bauknecht, and R. Kemp (Cheltenham: Edward Elgar), 103-130.

Kemp, R., Rotmans, J., and Loorbach, D. (2007). Assessing the Dutch energy transition policy: how does it deal with dilemmas of managing transitions? J. Environ. Pol. Plan. 9, 315-331. doi: 10.1080/15239080701622816

Kiko (2020). Official Homepage of Machizukuri Suishin Kiko NPO, the Institute for City Planning Promotion. Kamagawa Promenade Development Council and Special Committee for Kamagawa Utilization. Available online at: https://www. machidukuri.org/kamagawa/ (accessed March 11, 2020).

Konijnendijk, C. C., Ricard, R. M., Kenney, A., and Randrup, T. B. (2006). Defining urban forestry - a comparative perspective of North America and Europe. Urban For. Urban Green. 4, 93-103. doi: 10.1016/j.ufug.2005. 11.003

Kotsila, P., Matheney, A., Connolly, J., Anguelovski, I., and Dommerholt, T. (2020). Meta-Analysis of EU-Funded Projects: Drivers and Manifestations Of Injustice. Horizon 2020 Project UrbanA, Deliverable 4.1. Available online at: https://urban-arena.eu/wp-content/uploads/2020/05/D4.1_Driversand-manifestations-of-injustice_final.pdf

Kronenberg, J., and Andersson, E. (2019). Integrating social values with other value dimensions: parallel use vs. combination vs. full integration. Sustain. Sci. 14, 1283-1295. doi: 10.1007/s11625-019-0 0688-7

Lawrence, A., and Molteno, S. (2012). "From rationalism to reflexivity? Reflections on change in the UK Biodiversity Action Plan," in Reflexive Governance for Global Public Goods, eds E. Brousseau, T. Dedeurwaerdere, and B. Siebenhüner (Cambridge, MA: MIT Press), 283-298. doi: 10.7551/mitpress/9780262017244. 003.0276 
Lindner, R., Daimer, S., Beckert, B., Heyen, N., Koehler, J., Teufel, B., et al. (2016). Addressing directionality: orientation failure and the systems of innovation heuristic. Towards reflexive governance. Fraunhofer ISI Discuss. Pap. Innov. Syst. Policy Anal. 52, 1-40.

Maes, J., and Jacobs, S. (2017). Nature-based solutions for Europe's sustainable development. Conserv. Lett. 10, 121-124. doi: 10.1111/conl.12216

Masi, F., Rizzo, A., and Regelsberger, M. (2018). The role of constructed wetlands in a new circular economy, resource oriented, and ecosystem services paradigm. J. Environ. Manage. 216, 275-284. doi: 10.1016/j.jenvman.2017.11.086

Mattijssen, T. J. M., van der Jagt, A. P. N., Buijs, A. E., Elands, B. H. M., Erlwein, S., and Lafortezza, R. (2017). The long-term prospects of citizens managing urban green space: from place making to place-keeping? Urban For. Urban Green. 26, 78-84. doi: 10.1016/j.ufug.2017.05.015

McCormick, K., Anderberg, S., Coenen, L., and Neij, L. (2013). Advancing sustainable urban transformation. J. Clean. Prod. 50, 1-11. doi: 10.1016/j.jclepro.2013.01.003

McNutt, K., and Rayner, J. (2018). Is Learning without teaching possible? The productive tension between network governance and reflexivity. J. Environ. Policy Plan. 20, 769-780. doi: 10.1080/1523908X.2014.986568

Meadowcroft, J., and Steurer, R. (2018). Assessment practices in the policy and politics cycles: a contribution to reflexive governance for sustainable development? J. Environ. Policy Plan. 20, 734-751. doi: 10.1080/1523908X.2013.829750

Mees, H. L. P., and Driessen, P. P. J. (2011). Adaptation to climate change in urban areas: climate-greening London, Rotterdam, and Toronto. Clim. Law 2, 251-280. doi: 10.1163/CL-2011-036

Metze, T. A. P., and Van Zuydam, S. (2018). Pigs in the city: reflective deliberations on the boundary concept of agroparks in The Netherlands. J. Environ. Policy Plan. 20, 675-688. doi: 10.1080/1523908X.2013.819780

Ostrom, E. (2010). Beyond markets and states: polycentric governance of complex economic systems. Transnatl. Corp. Rev. 2, 1-12. doi: 10.1080/19186444.2010.11658229

Pahl-Wostl, C. (2009). A conceptual framework for analysing adaptive capacity and multi-level learning processes in resource governance regimes. Glob. Environ. Chang. 19, 354-365. doi: 10.1016/j.gloenvcha.2009.06.001

Patton, M. Q. (2014). Qualitative Research and Evaluation Methods - Integrating Theory and Practice. Thousand Oaks, CA: SAGE.

Perri 6, and Bellamy, C. (2011). Principles of Methodology: Research Design in Social Science. London: SAGE.

Peters, K., Elands, B., and Buijs, A. (2010). Social interactions in urban parks: stimulating social cohesion? Urban For. Urban Green. 9, 93-100. doi: 10.1016/j.ufug.2009.11.003

Pidgeon, N., and Henwood, K. (1997). "Using grounded theory in psychological research," in Doing Qualitative Analysis in Psychology, ed N. Hayes (Hove: Psychology Press), 245-273.

Pugh, T. A. M., MacKenzie, A. R., Whyatt, J. D., and Hewitt, C. N. (2012). Effectiveness of green infrastructure for improvement of air quality in urban street canyons. Environ. Sci. Technol. 46, 7692-7699. doi: 10.1021/es300826w

Randrup, T. B., Buijs, A., Konijnendijk, C. C., and Wild, T. (2020). Moving beyond the nature-based solutions discourse: introducing nature-based thinking. Urban Ecosyst. 23, 919-926. doi: 10.1007/s11252-020-00964-w

Rodríguez, I., Sletto, B., Bilbao, B., Sánchez-Rose, I., and Leal, A. (2018). Speaking of fire: reflexive governance in landscapes of social change and shifting local identities. J. Environ. Policy Plan. 20, 689-703. doi: 10.1080/1523908X.2013.766579

Ruggie, J. G. (2004). Reconstituting the global public domain - Issues, actors, and practices. Eur. J. Int. Relations 10, 499-531. doi: 10.1177/1354066104047847

Schlosberg, D. (2009). Defining Environmental Justice: Theories, Movements, and Nature. Oxford: Oxford University Press.

Scott, M., Lennon, M., Haase, D., Kazmierczak, A., Clabby, G., and Beatley, T. (2016). Nature-based solutions for the contemporary city/Re-naturing the city/Reflections on urban landscapes, ecosystems services and nature-based solutions in cities/Multifunctional green infrastructure and climate change adaptation: brownfield greening as an adaptation strategy for vulnerable communities?/Delivering green infrastructure through planning: insights from practice in Fingal, Ireland/Planning for biophilic cities: from theory to practice. Plan. Theor. Pract. 17, 267-300. doi: 10.1080/14649357.2016.1 158907
Slagstedt, J., Hammer, M., Emilsson, T., and Stålhamre, N. J. (2014). Mall för upprättande av skötselplan för biodiversa vegetationsytor. [Template for Maintenance Plan of Areas Covered With Biodiverse Vegetation]. BiodiverCity project. Available online at: https://malmo. se/download/18.4976695614b34cc6d2219cae/1491298544445/Sk\%c3 \%b6tselbeskrivningMALL2.pdf (accessed November 11, 2019).

Smith, A., and Raven, R. (2012). What is protective space? Reconsidering niches in transitions to sustainability. Res. Policy 41, 1025-1036. doi: 10.1016/j.respol.2011.12.012

Smith, A., and Stirling, A. (2010). The politics of social-ecological resilience and sustainable socio-technical transitions. Ecol. Soc. 15:11. doi: 10.5751/ES-03218-150111

Smith, A., Voß, J. P., and Grin, J. (2010). Innovation studies and sustainability transitions: the allure of the multi-level perspective and its challenges. Res. Policy 39, 435-448. doi: 10.1016/j.respol.2010.01.023

Sol, J., van der Wal, M. M., Beers, P. J., and Wals, A. E. J. (2018) Reframing the future: the role of reflexivity in governance networks in sustainability transitions. Environ. Educ. Res. 24, 1383-1405. doi: $10.1080 / 13504622.2017 .1402171$

Stirling, A. (2014). From sustainability to transformation: dynamics and diversity in reflexive governance of vulnerability. SPRU Working Paper Series 2014-06 (Brighton: University of Sussex). Available online at: https://papers.ssrn.com/ sol3/papers.cfm? abstract_id=2742113

Stripple, J., and Bulkeley, H. (2019). Towards a material politics of socio-technical transitions: navigating decarbonisation pathways in Malmö. Polit. Geogr. 72, 52-63. doi: 10.1016/j.polgeo.2019.04.001

Sugiyama, T., Francis, J., Middleton, N. J., Owen, N., and Giles-Corti, B. (2010). Associations between recreational walking and attractiveness, size, and proximity of neighborhood open spaces. Am. J. Public Health 100, 1752-1757. doi: 10.2105/AJPH.2009.182006

Sullivan, W. C., Kuo, F. E., and DePooter, S. F. (2004). The fruit of urban nature: vital neighborhood spaces. Environ. Behav. 36, 678-700. doi: 10.1177/0193841X04264945

Toxopeus, H., Kotsila, P., Conde, M., Katona, A., van der Jagt, A. P. N., and Polzin, F. (2020). How 'just' is hybrid governance of urban nature-based solutions? Cities 105:102839. doi: 10.1016/j.cities.2020.102839

Turnhout, E., Metze, T., Wyborn, C., Klenk, N., and Louder, E. (2020). The politics of co-production: participation, power, and transformation. Curr. Opin. Environ. Sustain. 42, 15-21. doi: 10.1016/j.cosust.2019.11.009

United Nations (2015). Transforming Our World: The 2030 Agenda for Sustainable Development. New York, NY: UN Doc. A/RES/70/1.

van Dam, R., Duineveld, M., and During, R. (2015). Delineating active citizenship: the subjectification of citizens' initiatives. J. Environ. Policy Plan. 17, 163-179. doi: 10.1080/1523908X.2014.918502

van den Berg, A. E., Hartig, T., and Staats, H. (2007). Preference for nature in urbanized societies: stress, restoration, and the pursuit of sustainability. J. Soc. Issues 63, 79-96. doi: 10.1111/j.1540-4560.2007.00497.x

van der Jagt, A. P. N., Craig, T., Brewer, M. J., and Pearson, D. G. (2017a). A view not to be missed: Salient scene content interferes with cognitive restoration. PLoS ONE 12:e0169997. doi: 10.1371/journal.pone. 0169997

van der Jagt, A. P. N., Elands, B. H. M., Ambrose-oji, B., Geroházi, É., Steen Møller, M., and Buizer, M. (2016). Participatory governance of urban green spaces: trends and practices in the EU. Nord. J. Archit. Res. 3, 11-40.

van der Jagt, A. P. N., and Lawrence, A. (2019). Local government and urban forest governance: insights from Scotland. Scand. J. For. Res. 34, 53-66. doi: $10.1080 / 02827581.2018 .1532018$

van der Jagt, A. P. N., Raven, R., Dorst, H., and Runhaar, H. (2020). Naturebased innovation systems. Environ. Innov. Soc. Transitions 35, 202-216. doi: $10.1016 /$ j.eist.2019.09.005

van der Jagt, A. P. N., Szaraz, L. R., Delshammar, T., Cvejić, R., Santos, A., Goodness, J., et al. (2017b). Cultivating nature-based solutions: the governance of communal urban gardens in the European Union. Environ. Res. 159, 264-275. doi: 10.1016/j.envres.2017.08.013

van Ham, C., and Klimmek, H. (2017). "Partnerships for nature-based solutions in urban areas-showcasing successful examples," in Nature-Based Solutions to Climate Change Adaptation in Urban Areas, eds N. Kabisch, H. Korn, J. Stadler, and A. Bonn (Cham: Springer), 275-289. 
Vinnova (2017). Biologisk mångfald i den täta staden - Tips och erfarenheter kring gröna lösningar. [Biodiversity in the Dense City - Tips and Experiences About Green Solutions]. Malmö: CA Andersson.

Voß, J., Bauknecht, D., and Kemp, R. (2006). Reflexive Governance for Sustainable Development. Cheltenham: Edward Elgar Publishing.

Voß, J., and Bornemann, B. (2011). The politics of reflexive governance: challenges for designing adaptive. Ecol. Soc. 16, 9. doi: 10.5751/ES-04051-160209

Voß, J., and Kemp, R. (2006). "Sustainability and reflexive government: introduction," in Reflexive Governance for Sustainable Development, eds J. Voß, D. Bauknecht, and R. Kemp (Cheltenham: Edward Elgar Publishing), 3-30.

Voß, J., Smith, A., and Grin, J. (2009). Designing long-term policy: rethinking transition management. Policy Sci. 42, 275-302. doi: 10.1007/s11077-009-9103-5

Walker, R. (2015). Building a better theory of the urban: a response to 'towards a new epistemology of the urban?'. City 19, 183-191. doi: 10.1080/13604813.2015.1024073

Wals, A. E. J., and Benavot, A. (2017). Can we meet the sustainability challenges? The role of education and lifelong learning. Eur. J. Educ. 52, 404-413. doi: $10.1111 /$ ejed.12250

Weiner, R. R. (2018). Les Reciproqueteurs: post-regulatory corporatism. J. Environ. Policy Plan. 20, 752-768. doi: 10.1080/1523908X.2014.947923
Wolch, J. R., Byrne, J., and Newell, J. P. (2014). Urban green space, public health, and environmental justice: the challenge of making cities "just green enough." Landsc. Urban Plan. 125, 234-244. doi: 10.1016/j.landurbplan.2014. 01.017

Wolfram, M., and Frantzeskaki, N. (2016). Cities and systemic change for sustainability: prevailing epistemologies and an emerging research agenda. Sustainability 8:144. doi: 10.3390/su8020144

Zhou, W., Fisher, B., and Pickett, S. T. A. (2019). Cities are hungry for actionable ecological knowledge. Front. Ecol. Environ. 17:135. doi: 10.1002/fee.2021

Conflict of Interest: The authors declare that the research was conducted in the absence of any commercial or financial relationships that could be construed as a potential conflict of interest.

Copyright (c) 2021 van der Jagt, Kiss, Hirose and Takahashi. This is an open-access article distributed under the terms of the Creative Commons Attribution License (CC $B Y)$. The use, distribution or reproduction in other forums is permitted, provided the original author(s) and the copyright owner(s) are credited and that the original publication in this journal is cited, in accordance with accepted academic practice. No use, distribution or reproduction is permitted which does not comply with these terms. 